\title{
DISTRIBUTION MAPS
}

I. Macrochelys temminckii . . . . . . . . . . . . 52

2. Subspecies of Chelydra serpentina . . . . . . . . . . 6r

3. Subspecies of Sternotherus carinatus . . . . . . . . . . 75

4. Sternotherus odoratus . . . . . . . . . . . . . . . . 83

5. Kinosternon f. flavescens and the subspecies of K. baurii . . . . . 96

6. Kinosternon sonoriense and the subspecies of K. subrubrum . . . 102

7. Clemmys guttata . . . . . . . . . . . . . . . . II4

8. Clemmys insculpta and the subspecies of C. marmorata . . . . . . I24

9. Clemmys muhlenbergii . . . . . . . . . . . . . 130

ı. Emys blandingii . . . . . . . . . . . . . . . . . . . I33

I I. Subspecies of Terrapene carolina . . . . . . . . . . . . . . I39

12. Terrapene ornata . . . . . . . . . . . . . . . . . 158

13. Subspecies of Malaclemys terrapin . . . . . . . . . . . 164

14. Graptemys barbouri, G. geographica, G. oculifera, and G. pulchra . . 195

15. Subspecies of Graptemys pseudogeographica . . . . . . . . . . 202

I6. Subspecies of Chrysemys picta . . . . . . . . . . . . . . . 215

17. Subspecies of Pseudemys scripta . . . . . . . . . . . . . 24I

18. Pseudemys nelsoni and the subspecies of P. rubriventris . . . . . 268

19. Subspecies of Pseudemys floridana . . . . . . . . . . . . . . 282

20. Deirochelys reticularia . . . . . . . . . . . . . . 317

21. Species of Gopherus .. . . . . . . . . . . . . . 322

22. Subspecies of Amyda ferox . . . . . . . . . . . . . 414

23. Amyda mutica . . . . . . . . . . . . . . . 436 